\title{
Miasta dla ludzi Jana Gehla - o społecznych konsekwencjach planowania przestrzennego
}

$25 / 2018$

Political Dialogues

DOI: http://dx.doi.org/10.12775/DP.2018.015

\begin{abstract}
:
The fundamental concept of Jan Gehl is the belief that spatial planning should take place with respect for the human dimension, and that the human senses should be taken as a starting point. Designing space should be given to the possibilities of man, so that during the walking trip it is possible to use various functions of the city. Jan Gehl's ideas have gained popularity and have been put into practice in many cities around the world.
\end{abstract}

Keywords: Jan Gehl; cities; city planning, architecture; postmodernism; human

Jan Gehl jest duńskim architektem i urbanista, którego idee sa obecnie jednymi z najbardziej wpływowych i majacych największe znaczenie dla planowania przestrzennego. Jan Gehl znany jest zarówno ze swojej pracy teoretycznej, jak i $z$ realizacji swoich teorii w praktyce. Spośród dzieł można w szczególności wymienić książkę Życie między budyn$k a m i{ }^{1}$, w której poświęca uwage temu,

1 J. Gehl, Życie między budynkami. Użytkowanie przestrzeni publicznych, tłum. M. A. Urbańska, Kraków 2009. w jaki sposób ludzie użytkuja przestrzenie publiczne w zależności od sposobu ich projektowania, Miasta dla ludzi², gdzie zajmuje się tym, jak rozwijać miasta, które sa dobre do życia, bezpieczne, zrównoważone i zdrowe. Koncentrujacc się na tych zagadnieniach, Gehl uznaje, że krajobraz miejski należy rozpatrywać przez pięć ludzkich zmysłów i z perspektywy prędkości pieszego, a nie prędkości jazdy samochodem. Znana praca jest także Public spaces. Public life ${ }^{3}$, która jest opisem zmian, jakie zaszły od lat 60. w śródmieściu Kopenhagi, w których udział miał Jan Gehl i dzięki którym rodzinne miasto urbanisty jest obecnie uważane za jedno $z$ najlepszych miast do życia. Jan Gehl był również konsultantem przebudowy przestrzeni miejskich między innymi w Londynie, Nowym Jorku, Moskwie czy Melbourne.

Postać Jana Gehla jest kojarzona $z$ rozwijajacym się od lat 70 . XX wieku i zaliczanym do postmodernizmu nurtem urbanistyki zwanym nowym urbanizmem. Przedstawiciele nowego urbani-

2 J. Gehl, Miasta dla ludzi, tłum. S. Nogalski, Kraków 2014.

3 J. Gehl, L. Gemzøe, Public spaces. Public life, Hørsholm 2004. 
zmu przy projektowaniu współczesnych przestrzeni miejskich nawiazuja do kompozycji tradycyjnych i historycznych miast europejskich. Dzięki zwartej zabudowie i mieszaniu funkcji większość miejskich aktywności znajduje się w zasięgu ruchu pieszego. Jednym $z$ najważniejszych przedstawicieli nowego urbanizmu jest Leon Krier - luksemburski architekt i urbanista. Poza krytyka modernistycznej architektury i urbanistyki (Architektura wspólnoty ${ }^{4}$ ) uosabianych przez takie postaci jak Le Corbusier, Oscar Niemeyer czy Ludwig Mies van der Rohe, Krier projektuje budynki w stylu New Classical architecture - stanowiacym nurt współczesnego historyzmu. Za prekursorkę nowego urbanizmu uznaje się często amerykańsko-kanadyjska dziennikarkę i aktywistkę miejską Jane Jacobs. Jej wydana w 1961 r. książka Śmierć $i$ życie wielkich miast Ameryki była krytyka wymierzona w ówcześnie dominujace metody planowania przestrzennego $^{5}$, a na podstawie własnych doświadczeń $\mathrm{z}$ mieszkania $\mathrm{w}$ dzielnicy Greenwich Village na nowojorskim Manhattanie autorka ukazuje w swoim dziele dobrodziejstwa płynace $z$ życia w tradycyjnie zaprojektowanym mieście. Idee zawarte w pracy Jane Jacobs stały się również inspiracją dla Jana Gehla, który wprost powołuje się na nią w swoich dziełach, zgadza się, że segregacja funkcji miejskich i skupienie się na budynkach-pomnikach, nie tworzacych razem integralnej całości, spowodowały śmierć przestrzeni miejskich i stwierdza, że „przekonująco opisała zalety i radość życia w mieście"6.

4 L. Krier, Architekturawspólnoty, tłum. P. Choynowski, Gdańsk 2011.

5 J. Jacobs, Śmierć $i$ życie wielkich miast Ameryki, tłum. Ł. Mojsak, Warszawa 2014, s. 21.

6 J. Gehl, Miasta..., s. 3 .
Fundamentalna koncepcja Jana Gehla jest przekonanie, że planowanie przestrzenne powinno odbywać się $z$ poszanowaniem ludzkiego wymiaru, a za punkt wyjścia należy obrać ludzkie zmysły $^{7}$. Projektować przestrzeń należy z myślą o możliwościach człowieka, tak, aby w czasie pieszej wycieczki możliwe było korzystanie $z$ różnych funkcji miasta. Idealna sytuacja byłoby, gdyby człowiek, wychodząc $z$ pracy i zmierzajac spacerem do mieszkania, mógł po drodze np. zrobić zakupy czy załatwić sprawy w urzędzie i nie musiałby w tym celu używać żadnego pojazdu, tam zaś, gdzie nie jest to możliwe, żeby podstawowym środkiem transportu był transport publiczny, który jest o wiele bardziej oszczędny w wykorzystaniu cennej miejskiej przestrzeni.

Modernistyczna urbanistykę, która zdominowała planowanie przestrzenne w latach powojennych, oskarża o to, że odrzuciła projektowanie przestrzeni miejskiej na rzecz projektowania pojedynczych budynków, które nie sa ze sobą wystarczajaco powiąane ${ }^{8}$. Powoduje to, że znika tradycyjne miasto $z$ jego wielofunkcyjnościa, a pojawiaja się obszary, które służą wyłącznie jednej funkcji: mieszkalnej, rekreacyjnej czy biznesowej. Tak radykalne dzielenie funkcji staje się przyczyna tego, że jedynym opłacalnym sposobem poruszania się między wydzielonymi obszarami modernistycznego miasta jest korzystanie $z$ indywidualnego transportu samochodowego. Wysoka zabudowa biznesowa w centrum i ekstensywna zabudowa mieszkalna na przedmieściach czynia sprawny transport publiczny ekonomicznym absurdem, poruszanie się po takiej przestrzeni może się odbywać wyłącznie samochodem, do tego stopnia, że staje

\footnotetext{
7 Ibidem, s. 33.

8 Ibidem, s. 4.
} 
się jedynym odpowiednim środkiem dojazdu nawet do osiedlowego sklepu9. Dominacja ruchu samochodowego skutkuje zaś opustoszeniem przestrzeni i ograniczeniem ulic wyłącznie do funkcji komunikacyjnej. W takim modelu przestrzeń publiczna jest przez ludzi postrzegana jako nieprzyjazna i służąca wyłącznie przemieszczeniu się $z$ jednego punktu do drugiego, nie ma w niej nic, co mogłoby zachęcić do korzystania $z$ niej w inny sposób. Konsekwencją tego jest erozja więzi społecznych, które do wykształcenia się i trwałego istnienia potrzebuja wielości sytuacji, w których różni ludzie moga się ze soba spotkać i nawiązać kontakt, co jest zdecydowanie utrudnione, gdy życie społeczne prowadzi się wyłącznie we wnętrzach budynków. Tymczasem to właśnie „życie między budynkami” ${ }^{10}$ powinno stanowić sedno życia społecznego i tylko ono może stać podstawą trwałych relacji społecznych.

Podstawowym rozróżnieniem w myśli Jana Gehla jest podział aktywności podejmowanej przez ludzi poza domem na trzy kategorie, a każda $z$ nich wymaga dla swojego rozwoju innego otoczenia ${ }^{11}$. Pierwsza $z$ nich sa działania konieczne - sa to działania, które ludzie musza podejmować niezależnie od jakości przestrzeni. Można do nich zaliczyć np. chodzenie do pracy lub szkoły, załatwianie spraw w urzędzie czy na poczcie. Choćby przestrzeń była nieprzyjazna i niskiej jakości, ludzie i tak będą musieli z niej korzystać w celu wykonywania działań koniecznych, dlatego ten rodzaj aktywności wykazuje podobny poziom przez cały rok i niezależnie od istniejących zewnętrznych warunków. Druga kategoria sa

9 J. Wesołowski, Miasto $w$ ruchu. Przewodnik po dobrych praktykach $w$ organizowaniu transportu miejskiego, Łódź 2008, s. 10.

10 J. Gehl, Życie..., s. 14.

${ }^{11}$ Ibidem, s. 9. działania opcjonalne, będące ściśle związane $z$ jakościa przestrzeni. Podejmowane sa $z$ własnej inicjatywy jednostek i uzależnione od ich woli. Może to być spacerowanie, czytanie książki w parku czy podziwianie zabytków. Jeżeli środowisko zewnętrzne nie stwarza odpowiednich warunków do podejmowania tego rodzaju aktywności, to ludzie decyduja się na pozostanie w domu. To, jaka będzie częstotliwość działań opcjonalnych, uzależnione jest od właściwego projektowaniem przestrzeni. Ostatnią wyróżniana przez Jana Gehla kategoria aktywności pozadomowej sa działania społeczne, zwane inaczej wynikowymi. Działania te sa konsekwencją wcześniejszych działań koniecznych i opcjonalnych. Uzależnione sa od obecności w publicznej przestrzeni innych ludzi. Ta kategoria obejmuje choćby powitania, rozmowy czy pożegnania. Intensywność działań społecznych zwiazana jest $z$ suma działań koniecznych i opcjonalnych i stanowi ich spontaniczny skutek. Jakość warunków zewnętrznych, które moga być kształtowane w procesie planowania przestrzennego, ma zasadnicze znaczenie dla tego, czy nastapi wzrost ludzkiej aktywności w przestrzeni publicznej. Jan Gehl przytacza badania przeprowadzone w centrum Kopenhagi, wskazujące, że między 1968 a 1986 rokiem, gdy przeprowadzono zmiany w przestrzeni publicznej, nastapił niemal trzykrotny wzrost ilości pieszych, zaś do 1995 roku wzrost nastapił o kolejne $20 \%{ }^{12}$.

Planowanie przestrzenne przynosi określone konsekwencje dla życia społecznego. To od konkretnych decyzji planistycznych zależy, jak będzie wyglądać miasto i jakie działania będa podejmować ludzie w nim mieszkający. Jan Gehl wskazuje, że w czasie planowania okre-

${ }^{12}$ Ibidem, s. 32-33. 
ślonej przestrzeni należy odpowiedzieć sobie na pytania: gromadzić czy rozpraszać, integrować czy segregować, zapraszać czy odstraszać, otwierać czy zamykać. Jest to pewien zestaw problemów, które osoby odpowiedzialne za kształt danej przestrzeni musza rozważyć, aby być $\mathrm{w}$ stanie projektować ja w sposób świadomy ${ }^{13}$. Odpowiedź na każde $z$ tych pytań powinna być dostosowania do potrzeb i oczekiwań wobec projektowanej przestrzeni. Jan Gehl w swoich pracach podaje wiele takich konkretnych dylematów, z których trzy przykładowe zostana poruszone w dalszej części artykułu.

Pierwszym możliwym dylematem jest kwestia - gromadzić na jednym poziomie czy rozpraszać na wielu. Duński urbanista zdecydowanie nie jest zwolennikiem wysokiej zabudowy. Ulica jest dla niego najważniejsza przestrzenią życia społecznego, a związek tej przestrzeni $z$ budynkami uznaje za kluczowy. Związek jest silny $\mathrm{w}$ przypadku budynków niskich, natomiast im wyższy budynek, tym słabszy jest związek, najwyższe budynki świata zaś sa w zasadzie całkowicie oddzielone od ulicy, same w sobie próbuja stać się miastami. Dominacja wysokich budynków w mieście powoduje, że większość aktywności skupia się w budynkach, natomiast ulice pustoszeja. Ponadto aktywności rozproszone między wieloma poziomami słabo na siebie oddziałują. Jan Gehl wskazuje, że określone funkcje, znajdujące się $50 \mathrm{~m}$ do $100 \mathrm{~m}$ w oddaleniu od siebie, maja mimo wszystko silniejszy związek, niż funkcje znajdujace się tylko 3 metry od siebie, ale umiejscowione na innych poziomach. Za pewna graniczna wysokość, powyżej której relacja między budynkiem a ulica znacząco słabnie, Jan Gehl uznaje wy-

13 Ibidem, s. 81. sokość 5 kondygnacji ${ }^{14}$. Niskie budynki tworzace pierzeję znaczaco bardziej odpowiadaja ludzkiemu sposobowi poruszania się i odbierania przestrzeni zmysłami niż samotne drapacze chmur.

Kolejnym pytaniem jest integrować ruch uliczny czy segregować. Jan Gehl, aby zobrazować problem, przedstawia cztery modele, które są reprezentowane przez cztery miasta: Los Angeles, Radburn, Delft i Wenecję ${ }^{15}$. Los Angeles to model integracji ruchu na warunkach ruchu samochodowego. Model taki jest prosty, układ dróg nieskomplikowany, jednocześnie przestrzeń odznacza się niskim poziomem bezpieczeństwa, a ulice nie maja innego zastosowania poza ruchem samochodowym. Radburn, osiedle miejskiego typu znajdujace się formalnie w mieście Fair Lawn w stanie New Jersey, zostało zaprojektowane przez amerykanskiego urbanistę Clarence'a Steina jako odpowiedź na problemy miast amerykańskich epoki industrialnej ${ }^{16}$. Opierało się na separacji ruchu samochodowego i pieszego. Wprowadzało skomplikowany układ dróg przeznaczonych oddzielnie dla samochodów i dla pieszych. Celem było zwiększenie bezpieczeństwa za pomoca oddalenia pieszych od samochodów. Jan Gehl wskazuje jednak, że taki system, jak wynika $z$ badań, wcale nie przyczynia się znaczaco do poprawy bezpieczeństwa, ponieważ ludzie często wybieraja krótsza, ale mniej bezpieczna drogę, niż droge specjalnie dedykowana pieszym, ale dłuższą. Podstawowym modelem zalecanym przez duńskiego urbanistę jest model $z$ Delftu. Jest to model integracji ruchu na warunkach ruchu pieszego.

14 Ibidem, s. 98-99.

15 Ibidem, s. 110.

${ }^{16}$ C-M. Lee, B. Stabin-Nesmith, The Continuing Value of a Planned Community: Radburn in the Evolution of Suburban Development, [w:] Journal of Urban Design, London 2001, s. 151. 
Pierwszy raz wprowadzony w tym holenderskim mieście w 1969 roku, opiera się na rodzaju ulicy, na której przyznaje się priorytet ruchowi pieszemu i rowerowemu, nie wykluczajac przy tym ruchu samochodowego i miejsc parkingowych. Ten rodzaj ulicy w języku niderlandzkim jest nazywany woonerf, co w wolnym tłumaczeniu oznacza „ulicę do mieszkania”. Taki system porządkowania ruchu godzi sprzeczne interesy użytkowników ruchu drogowego, zachowuje funkcję komunikacyjną ulicy dla różnego rodzaju pojazdów, ale jednocześnie umożliwia, aby ulica służyła również innych społecznym celom $^{17}$. Ważne w tym przypadku jest stosowanie środków uspokojenia ruchu i projektowanie odpowiedniej infrastruktury tak, aby sama ulica skłaniała użytkowników do założonych zachowań, a nie tylko znaki drogowe (nierzadki przypadek w Polsce, gdy stawia się znak oznaczajacy strefę zamieszkania, ale nie ida za tym właściwe dla tej strefy zmiany w przestrzeni, więc znak jest powszechnie ignorowany). Jan Gehl wskazuje, że ten rodzaj ulicy może w łatwy sposób znaleźć zastosowanie w w wielu miejscach, które obecnie są nieprzyjazne pieszym, ponieważ nie stanowi tak radykalnej zmiany jak całkowite zamknięcie ulicy dla innego ruchu niż ruch pieszy. Ostatnim $z$ modeli porzadkowania ruchu wskazanych przez duńskiego urbanistę jest model wenecki, a więc miasto piesze. Dany obszar udostepniony jest wyłacznie pieszym, natomiast ruch samochodowy kończy się na obrzeżach wyznaczonego obszaru. Odznacza się zdecydowanie najwyższym poziomem bezpieczeństwa, jest też prosty do wdrożenia, jednak nie może być stosowany tam, gdzie konieczne jest umożliwienie pojazdom zatrzymania się koło budynków. Powszechne

17 J. Wesołowski, Miasto..., s. 59. jest wyłaczanie $z$ ruchu samochodowego pojedynczych ulic i tworzenie deptaków, natomiast model jest rzadko stosowany w odniesieniu do całych osiedli. Jednym z przykładów takiego planowania jest osiedle Vauban we Frybugu Bryzgowijskim, w którym cała przestrzeń dedykowana jest pieszym, a miejsca postojowego dla samochodów znajduja się na zewnattrz osiedla ${ }^{18}$. Jan Gehl uznaje ten ostatni model za najlepszy i zaleca jego stosowanie we wszystkich przypadkach, gdy jest to możliwe, przyznając jednocześnie, że holenderski model woonerf jest również rozwiąaniem ze wszech miar do przyjęcia i powinien być stosowany, gdy niemożliwym do wdrożenia jest model wenecki.

Trzecia kwestia jest pytanie otwierać czy zamykać w kontekście sposobów parkowania $^{19}$. Pierwszym sposobem planowania miejsc postojowych jest wyznaczanie miejsc bezpośrednio przy wejściu do budynków. W takim przypadku ruch samochodowy przecina prostopadle ruch pieszy odbywajacy się na chodnikach. Sposób ten koresponduje $z$ modelem integracji na warunkach ruchu samochodowego i jako taki tworzy najmniej przyjazna przestrzeń dla niezmotoryzowanych użytkowników ruchu. Drugim sposobem jest wyznaczanie miejsc przy krawężniku, równolegle do ruchu innych użytkowników ulicy. Sposób taki jest dość powszechny na ulicach odpowiadajacych zasadzie woonerf, ponieważ dobrze godzi interesy pieszych i kierowców. Ulica może wtedy służyć innych funkcjom poza funkcją komunikacyjną. Ostatni sposób odpowiada modelowi weneckiemu, samochody zaparkowane sa na końcu drogi, a ostatni odcinek trzeba

${ }^{18}$ H. Linck, Carfree experienceinFreiburg-Vauban, http://www.atr.fc.it/admin/PagPar.php?op= fg\&id_pag_par=1317\&fld=file [dostęp: 10.09.2018].

19 J. Gehl, Życie..., s. 126. 
pokonać pieszo. W tym przypadku następuje intensyfikacja ruchu pieszego, który zastępuje ruch samochodowy, na co wskazuja przytaczane przez Jana Gehla badania przeprowadzone w Melbourne ${ }^{20}$.

$Z$ teorią miasta Jana Gehla łączy się przekonanie, że zaplanowana przestrzeń miejska ma przełożenie na zachowania ludzkie i na sposób, w jaki miasta funkcjonuja. To znaczy, że najpierw ludzie kształtuja miasta, a potem to miasta kształtują ludzi. I tak na przyklad miasta zakładane przez Rzymian na podbitych terenach ukazuja militarne przeznaczenie tych ośrodków, a Haussmannowska przebudowa Paryża doprowadziła do narodzenia się specyficznej „kultury bulwarowej"21. Również XX-wieczna urbanistyka miała swoje konsekwencje - w przestrzeni zaprojektowanej z myśla przede wszystkim o szybkim ruchu samochodowym to samochody wypełniły całą dostępna przestrzeń miejską, a próby zapobieżenia korkom samochodowym za pomoca budowy nowych dróg za każdym razem doprowadzały do tego, że również ta nowa przestrzeń była wkrótce w całości wypełniana. Jan Gehl dowodzi, że to zmniejszenie dostępnej przestrzeni dla samochodów prowadzi do obniżenia natężenia ruchu samochodowego, podając jako jeden $z$ przykładów zniszczenie w wyniku trzęsienia ziemi w 1989 r. autostrady Embarcadero Freeway, która prowadziła do centrum San Francisco. Początkowo władze planowały jak najszybciej ją odbudować, ponieważ stanowiła jeden $z$ głównym ciagów komunikacyjnych, wkrótce jednak stwierdzono, że kierowcy przystosowali się do nowej sytuacji i miasto dobrze sobie radzi bez niej. Obecnie w miejscu dawnej auto-

20 J. Gehl et al., The Interface Beetween Public and Private Territories in Residential Areas, Melbourne 1977, [cyt. za:] Ibidem.

21 J. Geh1, Miasta..., s. 9. strady znajduje się obsadzony szpalerami drzew bulwar z szerokimi chodnikami i linia tramwajowa.

Jan Gehl wskazuje, że walka o jakość przestrzeni odbywa się w małej skali. Dowodzi, że znaczenie dla jakości życia w mieście i relacji społecznych maja nie tylko wielkie projekty urbanistyczne, ale też drobne elementy $\mathrm{w}$ przestrzeni miejskiej, jak choćby rodzaj i umiejscowienie ławek, obecność albo brak półprywatnych ogródków frontowych czy typ i natężenie oświetlenia. Punktem wyjścia dla dobrego planowania przestrzennego powinny być proste i zwykłe aktywności podejmowane przez ludzi ${ }^{22}$. Duński urbanista jest zwolennikiem raczej powolnych i stopniowych zmian, ponieważ nagłe i radykalne zmiany moga wywołać sprzeciw ludzi przyzwyczajonych do już istniejącego modelu przestrzeni i w konsekwencji zaprzepaścić jakąkolwiek możliwość poprawy miasta. Wychodzi z założenia, że jeżeli chociaż jedna ulica zostanie na poczatek przekształcona w przyjazna przestrzeń i będzie działać, to ludzie zauważą to i będa chcieli podobnych zmian również $\mathrm{w}$ swoich okolicach, a stopniowo wprowadzane małe zmiany $z$ czasem przynosza znaczące podwyższenie jakości przestrzeni. Celem zaś projektowania urbanistycznego powinno być miasto dla ludzi - to jest miejsce pełne życia, bezpieczne, zrównoważone i zdrowe.

Miasto pełne życia, ponieważ przestrzeń postrzegana przez ludzi jako przyjazna zachęca ich do pozostania i korzystania $z$ niej, a wynikiem tego jest wzrost zachowań społecznych pomiędzy obecnymi w przestrzeni osobami. Miasto bezpieczne, gdyż obecność ludzi na ulicach wzmacnia naturalna i spontaniczną kontrolę społeczna, a ponadto przestrzeń

22 Ibidem, s. 118 
wysokiej jakości zdecydowanie częściej będzie przez jej użytkowników uznawana za "swoja”, a to zapobiega obojętności na to, co się w niej dzieje. Miasto zrównoważone oznacza, że miasto takie stara się nie eksploatować środowiska naturalnego ponad miare - zapewnia to zwarta i niezbyt wysoka zabudowa, a także zorientowanie na podróże piesze, rowerowe i transportem publicznym, dzięki czemu ogranicza się zużycie zasobów, emisję zanieczyszczeń czy natężenie hałasu. Miastem zdrowym jest miasto, w którym chodzenie czy jazda na rowerze stanowia część zwyczajnych, codziennych ludzkich aktywności. Zapobiega to problemom, które wiażą się $z$ dominacją siedzacego trybu życia. Te cztery cele powinny mieć na uwadze osoby odpowiedzialne za planowanie urbanistyczne, ponieważ według Jana Gehla skuteczne spełnianie ich jest kluczem do stworzenia miasta odpowiadającego potrzebom nowoczesnych społeczeństw ${ }^{23}$.

Idee Jana Gehla zyskały popularność i zostały zastosowane $\mathrm{w}$ praktyce $\mathrm{w}$ wielu miastach na całym świecie, ale szczególnie wiele realizacji jego koncepcji można odnaleźć w krajach skandynawskich, w tym w rodzinnym mieście urbanisty - Kopenhadze. W latach 60. Kopenhaga niewiele różniła się od typowego powojennego miasta zachodnioeuropejskiego. Stare śródmieście poprzecinane było drogami tranzytowymi, a dojazd $z$ jednorodzinnej zabudowy przedmiejskiej był realizowany przede wszystkim przez indywidualny transport samochodowy. Oczywistym skutkiem takiego modelu urbanistycznego były korki, wzrost zanieczyszczenia powietrza $\mathrm{w}$ mieście, osiedla-sypialnie, które nie pełniły żadnej innej funkcji poza mieszkalna czy depopulacja śródmieścia, które postrze-

\footnotetext{
${ }^{23}$ Ibidem, s. 6-7.
}

gane było jako miejsce nieprzyjazne i nienadajace się do mieszkania $\mathrm{w}$ nim. Jedna $z$ pierwszych decyzji było ustanowienie w 1962 r. ulicy Strøget jako strefy pieszej o długości 1100 metrów, w momencie powstania był to najdłuższy deptak na świecie. W tym czasie handlowcy obawiali się, że spadnie sprzedaż w ich sklepach, pojawiały się również opinie, że strefy piesze sa odpowiednie dla ciepłych krajów śródziemnomorskich, ale na północy nie maja racji bytu. Dzisiaj jednak jest to jedna $z$ największych atrakcji Kopenhagi i największa ulica handlowa duńskiej stolicy. W innych miejscach tworzono strefy uspokojonego ruchu, zachęcające do przemieszczania się pieszo i rowerem. Dzięki temu obecnie około połowa wszystkich podróży w Kopenhadze to podróże piesze i rowerowe ${ }^{24}$. Liczba podróży samochodowych konsekwentnie spada, a rowerowych rośnie ${ }^{25}$. Projektując nowe przestrzenie w Kopenhadze, zgodnie $z$ rada Jana Gehla, stosuje się nowoczesną architekturę, ale nawiązujaca do tradycyjnego modelu miasta urbanistykę. Tworzy się zwartą zabudowę i miesza funkcje miejskie. Dzięki temu unika się zarówno pastiszu historycznych form, jak i błędów urbanistyki modernistycznej. I tak, w 2014 stolica Danii trzeci raz została przez czasopismo Monocle uznana za miasto najlepsze do życia ${ }^{26}$, wyprzedzając Tokio i Melbourne, a w 2016 Kopenhaga wygrała w rankingu magazynu Metropolis na najlepsze miasto do zamieszkania ${ }^{27}$, wyprzedając

${ }^{24}$ http://www.epomm.eu/tems/result_city. phtml?city=227\&map=1 [dostęp: 10.09.2018] .

${ }^{25}$ http://www.cycling-embassy.dk/wp-content/uploads/2015/05/Copenhagens-Biycle-Account-2014.pdf [dostęp: 10.09.2018].

${ }^{26}$ http://denmark.dk/en/green-living/copenhagen/most-liveable-city-copenhagen [dostęp: 10.09.2018].

27 https://www.metropolismag.com/cities/ the-best-cities-to-live-in [dostęp: 10.09.2018]. 
Berlin oraz Helsinki. Duży udział w tym sukcesie ma Jan Gehl, zarówno bezpośrednio jako konsultant i projektant, jak i autorytet dla innych urbanistów.

\section{Bibliografia}

Gehl J., Miasta dla ludzi, tłum. S. Nogalski, Kraków 2014.

Gehl J., Gemzøe L., Public spaces. Public life, Hørsholm 2004.

Gehl J. et al., The Interface Beetween Public and Private Territories in Residential Areas, Melbourne 1977.

Gehl J., Życie między budynkami. Użytkowanie przestrzeni publicznych, tłum. M. A. Urbańska, Kraków 2009.

Jacobs J., Śmierć $i$ życie wielkich miast Ameryki, tłum. Ł. Mojsak, Warszawa 2014.

Krier L., Architektura wspólnoty, tłum. P. Choynowski, Gdańsk 2011.

Lee C-M., Stabin-Nesmith B., The Continuing Value of a Planned Community: Radburn in the Evolution of Suburban Development, [w:] Journal of Urban Design, London 2001.
Linck H., Car free experience in Freiburg-Vauban, http://www.atr.fc.it/admin/ PagPar.php?op=fg\&id_pag_par=1317\&fl$\mathrm{d}=$ file [dostęp: 10.09.2018].

Wesołowski J., Miasto w ruchu. Przewodnik po dobrych praktykach $w$ organizowaniu transportu miejskiego, Łódź 2008.

http: / / www.epomm.eu / tems / result_ city.phtml?city=227\&map=1 [dostep: 10.09.2018].

http: / / www.cycling-embassy.dk/wp-content/uploads / 2015/05/Copenhagens-Biycle-Account-2014.pdf [dostęp: 10.09.2018].

http:/ /denmark.dk/en/green-living/copenhagen/most-liveable-city-copenhagen [dostęp: 10.09.2018].

https: / / www.metropolismag.com / cities/the-best-cities-to-live-in [dostęp: 10.09.2018]. 